\title{
Ferenc Toldy and the Emergence of the Modern Hungarian Author ${ }^{1}$
}

\author{
Gergő Balogh
}

\begin{abstract}
Those who can read and write join the dynamic system of producing and receiving texts and become economic factors and subjects to author's and publication rights where applicable. The general effort to spread literacy, the significant increase in the number of potential authors caused by the legal obligations and educational practices of public schools in Eötvös's time, the shifts in the status of authorship, along with the broadening publicity in the media due to the sudden rise of journals made the modern regularization of producing, distributing and reproducing texts inescapable in Hungary in the last third of the nineteenth century. If a dimension in the history of education is responsible for producing the authors and readers who are able to create and accept modern literature in the interest of founding the modern literary consciousness, then the legal and economic contexts reformed in the last third of the nineteenth century are responsible for the institutionalization of authorship, for outlining and stabilizing authorial, press and reading subjects, as well as the relationship between author and text. This study aims to analyze the modern authorial subject's legal constitution, and the role of Ferenc Toldy in inaugurating it.
\end{abstract}

Keywords: Hungarian literature; Foucault; literary theory; authorship

Subject-Affiliation in New CEEOL: Language and Literature - Studies of Literature - Hungarian Literature

DOI: $10.36007 /$ eruedu.2020.4.052-065

The creation of the modern author's figure does not only take place in the legal dimension of founding the modern literary consciousness, but without this dimension, we could hardly talk about the process at all. This legal-economic dimension of founding the modern literary consciousness defines the modern Hungarian author as such. This dimension enables the production of literary works to enter the economy of a social system that has its own norms and rules, one that is already distinct but can never become fully independent from its environment. The historical analysis of the discussion on author's rights covers not just the regulations of cultural production and the various forms available in creating the modern authorial subject, as the passages of modern legal protection for author's rights pertinent to literature are crucial in thinking about literature, its cultural role, the author and their work, or in other words: they are essential in examining the literary approach(es) that have described Hungarian literary modernity since the nineteenth century and onwards to the twentieth century.

1 The writing of this paper was supported by the research program MTA BTK Lendület Magyar Irodalom Politikai Gazdaságtana Kutatócsoport (34080 LP 2019-10/2019). 


\section{The Author as Function: Constitution, Lack and Surplus}

Martha Woodmansee, researcher of economic correlations in the history of aesthetics, makes a witty though oversimplified claim with her eyes set primarily on the German, English and American contexts, saying that the historical figure of the modern author, that is, the individual who produces unique works (unique in breaking with tradition) and fills a distinguished position in cultural production, is a sort of "by-product" of Romanticism's origin myths (Woodmansee, 1994a, 16.). Although, as Woodmansee herself indicates elsewhere (Woodmansee, 1994b, 35-55.), the matter of the modern author cannot be observed independently from national traditions, from regional economic and sociocultural factors (for instance, one must contemplate the differences between the Anglo-American copyright (Betting, 1996, 9-32.) and the continental author's rights, and accordingly, between the two types of authorial models [Bodó, 2011, 109.]). The author's appearance cannot be reduced to be the by-product of a rhetorical period's central term, but - and here lies the problem - the emergence of the modern author still can be considered as a general phenomenon in Europe (even though it happened with major delay and with major differences in some cases).

The author is not a substance - it has to be made. Responding to Foucault's classical text, What is an Author?, there was keen interest in the investigation of the modern author and this institute's production and conditions of possibility from legal, economic and/or cultural perspectives in the last decades of the twentieth century. Among these, the legal dimension stands out the most, as Foucault already observed. According to him, who/what is called an author is

"tied to the legal and institutional systems that circumscribe, determine, and articulate the realms of discourses; it does not operate in a uniform manner in all discourses, at all times, and in any given culture; it is not defined by the spontaneous attribution of a text to its creator, but through a series of precise and complex procedures; it does not refer, purely and simply, to an actual individual insofar as it simultaneously gives rise to a variety of egos and to a series of subjective positions that individuals of any class may come to occupy." (Foucault, 1996, 130-131.)

For Foucault, the author is an extremely variable function of the text or discourse, which is created through the communicational exchange between text and reader, a function that, in the ideal case, adheres a legal person (or the lack of this person, or perhaps a virtual persona) to the text in modernity, a function defined by the discourses surrounding this domain, the actual social and cultural state, the range of operations available to be performed, and the institutional system's framework prescribing and validating these operations.

Here, with regard to this paper's argument, a differentiation in methodology must be made. Thinking along Foucault's thesis, one could say that the author's function is not equal to the author's constitution, but it encompasses the latter. The act stabilizing the connection between text and author creates an event that attaches the figure to the text in a form or manner defined by some historical-cultural context, yet does so in a way that the possibility for historical rearrangement is involuntarily and always left open. Therefore, the modern form of the authorial function is born from 
the interplay of the authorship's constitution and this constitution's adherence to a text or discourse. As a lack, the requirement of adherence ("a series of precise and complex procedures") is inscribed into the modern author's constitution, which transgresses it but cannot be treated independently: the modern necessity of adherence is the text's lack and surplus at the same time; an inscription which the reader encounters as a (historical-cultural) given and simultaneously, a vacant position, one to be made through the reader's activity; a constant, as contrasted with the figure adhered to it, who can never be constant. While adherence can be seen as a common point in the structure of authorial function in European modernity, constitution appears to be its variable. It would be a mistake to think of the author as a universal, transcultural and -historical category. As the modern view on the author's figure is first delimited by legal discourses, these must be attributed great importance if one aims to grasp this variable figure (of speech). As long as intellectual property as such exists, the modern author will also exist. Understanding this central correlation in modern literary consciousness is essential in interpreting the history of modern Hungarian literature.

\section{What is the Modern Hungarian Author?}

From the perspective of literary studies, the real difficulties in making the modern Hungarian author lie in the nature of the modern author's category noted above: in the dual and interwoven quality of function and constitution leading to a concurrently local and global, aporetic character.

In the classical notions of the modern Hungarian author, which have gained legitimacy implicitly or explicitly again and again in dealing with literature, tackling differences can never become dominant, as these models of authorship tend to earn legitimacy exactly from the similarities with international examples or parallels shown in literary history - that's a tradition reaching back to the self-definitions connected to the Nyugat circle. However, as Mihály Szegedy-Maszák also notes (Szegedy-Maszák, 2008, 128-129.), the belief in a homogeneous modernity - as well as in the figure of the modern author taking a unitary shape or the like, one may add - leaves a lot to be desired. The modern Hungarian author, though it would be a waste to ignore the perspective of this comparison, is often reduced to the modern constant known from international models, which enables literary historical analogies: the possibility for the act of adherence as essential; function's emerged surplus that contains and overwrites the constitution, opening the way for the author removed from the international literary discourses to become a sample for the modern Hungarian author. The surplus in function that takes the place of constitution makes it impossible to put the authorial figure's historical-cultural uniqueness in the center of investigation. For Hungarian literary historical tradition, the biggest difficulty is in answering the simple question of how the modern Hungarian author is any different from the French, the German or the Austrian regarding its constitution (and not its function, as there are no differences in that aspect). Foucault's question must be rephrased as follows from the perspective of founding the mod- 
ern literary consciousness: what is the modern Hungarian author?

An aspect that cannot be neglected is the book publishing market's development, varying greatly by countries: while the English and French press industry was able to allow its authors to make a living already in the eighteenth century, and writing literature in these countries could ensure decent existence at the beginning of the nineteenth century (Bodó, 2011, 99; Barbier - Lavenir, 2000), in Hungary, it was only from the last third of the nineteenth century that authors could live by their intellectual products. This period is dated from Mór Jókai's exemplary oeuvre and literary activities, who here is viewed as the first modern Hungarian author in a simultaneously economic (Lugosi, 2007, 396), legal and (sometimes) poetic sense. Looking at the number of operating press houses and the copies published at the time, Hungarian book publication was at a significant disadvantage compared to western Europe (Hansági, 2014, 196-202.), as a result of which the rapidly developing system of periodicals became the primary option for authors to earn a living starting from the first decades of the nineteenth century - and remained so for more than a hundred years (the forced nationalizations of journals and closing them down around the middle of the twentieth century brought an end to this period). Among many others, this created the opportunity for Jókai to become independent as a writer, and actually, for him this was also the option to turn towards his vocation for literature instead of starting to work as a lawyer. It is very telling that Jókai first felt the need to make a writer's existence appear economically legitimate, to prove that living as a writer will not cause his demise, when he began hinting at changing careers and told his parents about his successes and plans in his new profession (Szajbély, 2010, 20-26.).

Nineteenth-century political papers and fashion magazines allowed for a glimpse at the economic background of literary work and started to outline the modern authorial subject, who was not necessarily imaginable solely in a male figure - to Pál Gyulai's sorrow (Török, 2016.). In parallel with the emergence of professional writing in the second half of the nineteenth century, multiple cracks appeared on the male-centric, classical paradigm of authorship. This process cannot be viewed independently from the fact that the female readership, who was gaining more economical weight from the middle of the nineteenth century and had actual or imaginary demands, joined in creating the literary text's horizon of expectation - establishing, among other things, the feminine value by the start of the twentieth century, and turning it into an authorial virtue: the man who put on a feminine or female mask (an example for the latter would be Hugó Ignotus as Lady Emma in the journal $A$ Hét [Ignotus, 1985.]) could address a remarkably broad target audience, though only accounted for since the reform era, but one that increased the author's chance at economic success besides granting fame.

The slow abolishment of the male-centric paradigm of authorship, which is an essential part in constituting the modern author, cannot be alienated from the fact that in Hungary, only the 1868 reforms in Eötvös type public schools (Balogh, 2017) compelled both boys and girls to go to school, which means that compulsory school attendance between the age of six and twelve only became universal in this period. Without the educational program aiming to make the entire population 
literate, the successes of public school and the internationally prominent efficiency shown in teaching writing and reading, those women who contributed to the foundation of modern literary consciousness as readers and authors, consumers and creators (thus closing the circle that leads from the author through the reader then back to the author [Kittler, 1995, 138-158.]) could have hardly appeared. No longer to be ignored, they emerge in the nineteenth century, but attain their real significance only in the 1900s due to social modernization (Népszámlálás, 1871, 228; 1893, 152; 1920, 87; 1941, 65. Papp - Sipos, 2017, 122-128.). They cannot be overlooked even when talked about disdainfully with a half-smile in the majority of cases through the first decades of the twentieth century, or when they are defined almost as males, likened to the author's classical figure eminently known as male, as it happened with Margit Kaffka (Ady, 1918, 789-790.).

The developing literary system - within the borders of a slowly emancipating literary field - offered a chance for authors to concentrate solely on writing or maybe editorial work, free from all the daily encumbrances of civil professions. The forums of civilian publicity replaced those of class-based publicity in the first half of the nineteenth century, and opened the way for the institutionalization of literary production (Völgyesi, 2007, 24). Of course this does not mean that a mass of people engaged in professional writing swarmed the country after having recognized the opportunity and answering the call of their time. Sándor Petöfi was able to make a living exclusively from writing and editing long before Jókai, exploiting the developing literary system's, or in István Margócsy's words, the "modern literary machinery's" ascensional power (Margócsy, 1999, 48-74.), but his is a singular phenomenon and was thought to be unreproducible for long - and it cannot be fully explained by the institutional system's collapse in the period of the revolution and the ensuing retribution, which put Hungarian press on a life support system for over a decade. In the first half of the nineteenth century in Hungary, as it might be apparent from the beginning of Jokai's career, it was far from obvious that writers could act as representatives of the same occupation.

The emergence of Magyar Írói Segélyegylet around the middle of the century, an association with acclaimed authors in its chairmanship, attests that while writers asking for and accepting money (Toldy, 1838, 711-712.) for their eponymous activity (not to mention the seemingly absurd concept of social benefits) used to meet with indignation, the association stood up against this social prejudice and approached its readership with an attempt to legitimize writing as a profession (T. Szabó, 2008, 285-338; Szajbély, 2005, 305-308.). As regards the dubious state (and essence) of professional writing in Hungary in the middle of the nineteenth century, it is worth noting that the conditions of possibility for the professionalization of writing were much behind the international context: in the United States of America, the first laws concerned with copyright were declared as early as 1790 , and in France, to take an example not so remote from Hungarian codification - and partly as it stands closer to the continental legal practice - , a copyright act to protect author's rights and acknowledge writers as economic factors up to ten years after their death through the transferability of exclusivity was in effect since 1793 (Bodó, 2011, 108.). In contrast, it was only in the last third of the nineteenth centu- 
ry when the author's position reached a reassuring status in Hungary. As Levente T. Szabó points out, in nineteenth-century Hungary the discussion on author's rights implicitly codified and created a hierarchy between the factors that could play a role in the creation of a literary work. One of the first tasks of this discourse was to detach the author's role (and authorship as a modern type of profession) from those that traditionally competed with the author's in the creation of the literary work: namely, the inspiration's, the publisher's, the typographer's, the distributor's etc. roles. While this discourse sees the latter aspects as peripheral, and the author's as essential and foundational in creating the literary work, it canonized a definition of the author, which represents the literary work as the result of an intellectual, rather than a technical process, with the writer as its primary creator and lawful owner (preceding its inspiration, publisher, typographer, distributor etc.). (T. Szabó, 2011a, 572.)

Publication and author's rights became regulated rather late by Hungarian law, in 1884, when an authorial model was created and endorsed in order to protect the writer's interests above all, as opposed to, for example, the Anglo-American copyright that emphasized press interests over authorial ones. The 1793 prohibition of reprinting, an act that was in effect in the hereditary possessions of the Austro-Hungarian Monarchy was also applied to Hungary (Völgyesi, 2007, 25.), and was repealed only in 1884 (Mezei, 2004), but it was not really interested in the essence of authorship, just wanted to abate the fraudulent practices in press competition, and for this reason, it entertained a vastly different concept of the author (treated it as a marginal figure) than the sixteenth article of the law in regard author's rights, 1884. For this law to be passed as author's rights, was far from evident: Károly Eötvös, fueled by language preservation, a motivation that in that form felt odd - but certainly understandable by his logic - at the end of the nineteenth century, disapproved of the word author ('szerzöi') to be used in the law's title during its debate in the parliament (Eötvös, 1884, 164-165.), adverting to various semantic domains (creating/owning) of authoring ('szerzés'). This suggests, along with the reactions to the above comment that the author ('szerzö') signifier was still, in a sense, assailable in the last third of the nineteenth century, even though a bit anachronistically, which means that the concept of the author was not even used in its modern sense in terms of language.

The strongly protectionist view, which favored the authorial perspective over the publisher (e.g. article XVI, section 5 of 1884; article LIV, section 5 of 1921) and the intellectual property itself, aimed to protect the author as an economic agent and could become institutionalized in Hungary without major problems, leaving behind other contemporary alternatives known from the European legal systems, because the vindictive approach to author's rights was not only easy to integrate into the scheme of national responsibility, but it already had a designated position on a structural level: the nineteenth-century efforts to protect and build the nation appeared in economic and ideological dimensions alike and saw a chance to safeguard the nation and ensure its survival in the creation and protection of author's rights (T. Szabó, 2011a, 574-577.). One of the contributors is the genius author able to showcase extraordinary performance, and the other is the literary work writ- 
ten in Hungarian that will be owned by the community a certain time after the death of the author and will enrich the nation's cultural treasury and is able to perform the nation's cultural self-justification. It becomes truly clear only from this perspective why the genius is not the side product of Romanticism's origin myth: creating the figure of the genius and originality is a legitimizing move for nation-building and its subject, the national community - but above all, for the self-identical national spirit imbued with the power to create. Producing the myth of originality is a function of national discourses.

Attempts at establishing author's rights employ the above vindictive logic already from the 1840s. As Orsolya Völgyesi says, the proposal of author's rights made by the Kisfaludy Társaság in 1844 (though never sanctioned, still significant) also approached the protection of author's rights with an eye on one of the period's key terms, "nationality" and the need to strengthen it (Völgyesi, 2007, 29.). This sort of vindication, which was also present at the birth of Hungarian literary studies, and could be traced back to the historia litteraria of the eighteenth century (Dávidházi, 2004, 169-177; Tüskés, 2006.), had a major impact on the possible models of the Hungarian modern author: Hungarian literary modernism at the beginning of the twentieth century, which started out as the lingering image of Romanticism (a period which never fully ended in Hungary) and made a hero of the text's author, and the resurfacing (Bednanics, 2009, 183-186.) poetics of lyric subjectivity in the last decades of the nineteenth century that picked up new strength with the poems of Endre Ady and the first volume of Dezsö Kosztolányi (Kulcsár Szabó, 1996, 29-34.), and made a central trope of the reader's involvement with the writer. This relationship is created during reading and according to János Horváth, who elaborated on the paradigmatic concept of modern Hungarian literature, it is "literature's constant" essence, and as such, it is a "foundational relation" ('alapviszony'), which can integrate the dimensions of moral, historic and national community in the aspects of literary communication (Horváth, 2005, 73; Kulcsár-Szabó, 2006, 40-44.).

\section{Ferenc Toldy on Author's Rights}

As we saw, the modern Hungarian author is not the twentieth century's product. Its figure is rooted partly in the nineteenth century, and partly on a deeper level, in the eighteenth century, as the logic of vindication has unavoidably entered the modern author's constitution in Hungary. Nonetheless, dealing with author's rights - which discussion took the direction for the codification from the start (enlarging the at the time virtual discourse of author's rights with proposals, comments and criticism) became an apparently more and more collective matter of the intelligentsia only in the course of the nineteenth century.

Ferenc Toldy's publications on the topic of author's rights are some of the most noteworthy contributions to the subject in the middle of the nineteenth century. In his 1838 work entitled A Few Words on Author's Property and a Plea for Journal Publishers ('Néhány szó a szerzői tulajdonról. s kérelem a folyóiratok kia- 
dóihoz'), Toldy argues against the practice of republishing apropos of a Ferenc Kölcsey article that was originally published in Athenæum and republished elsewhere, as this phenomenon was causing problems on national and international levels alike. Toldy stood up against the republishing of works by disregarding the original publisher and all the rights it owns, or in some cases, the republishing of an author's works after their death, thus impairing the inheritor's rights. According to Toldy, this national and international practice (virulent in spite of the late eighteenth-century act mentioned above) ignores the fact that by natural law it is the author, who remains the work's possessor under all circumstances, irrespective of the publisher buying the text's publication right, and this also implies that only the author may decide who can publish his or her intellectual property.

The effort to help forward the codification of author's rights in Hungary - inscribing the inherent conflict of public benefit and individual interest into the constitution of modernity - excepts the text from the economy of free knowledge transfer, which the Enlightenment treated so sensitively. At the same time, one may notice that for Toldy, literary authorship has, without a doubt, reached a phase in the history of its professionalization where it can be treated as equal to other occupations (but it is not yet treated so: hence the problem), and as a result, literary work can be viewed as a manifestation of professionalism (Völgyesi, 2007, 26-27.). For writing to be treated as a real profession, and as such, a modern form of occupation, it must enter the economic dimension, but to do so, it needs legal guarantee. Toldy's thoughts that had a major influence on thinking about the modern author are founded on the following principles:

The subject matter of the present paper is a type of "internal estate", which becomes external property by publishing our intellectual works in print, but even in that form it remains, indeed, an inalienable property by natural right, and it does so in a threefold way; for one, it is an original estate, viz. it is the fruit of our freely grown inborn powers and talents (precinct); second, it is an acquired estate, for one to train themselves as a writer, time - during which one could be in search of any other material estate instead, preparations, and material resources are required, which necessitate expenditure (invested capital); but finally, it is an estate that warrants respect also from a moral perspective, as the fruit of the noblest talents used for the noblest causes (public virtue). [...] Since upon binding our thoughts to a material through a set of material signs and thus turning them into an object, and transferring this object in any way - by gifting or selling it - is to be understood as a conditional act: we do not sell the work, the mind's product and with it the right to reprint, but we sell an individual object, a copy or a number of copies. (Toldy, 1838, 705-706.) ${ }^{2}$

2 „A jelen értekezés tárgy a belső birtok azon neme, melly szellemi munkáinknak nyomtatásbani közlése által külső tulajdonná leszen, de így is, s pedig természetjog szerint is, igaz, elidegenithetetlen tulajdon, s háromszorosan az, mert egyfelül eredeti birtok, t. i. velünk született erök és tehetségek szabad kifejlésének gyümölcse (telek); másfelül szerzett birtok, mert arra, hogy ki magát iróul képezhesse, idő - melly alatt e helyett bármi materiális birtokot kereshetne, készületek, s materiális eszközök szükségesek, mellyek költséggel járnak (investitionalis töke); de végül erkölcsi tekintetben is mindenek felett tisztelendö birtok, mint a melly a legnemesb tehetségek legnemesb czélokra fordításának gyümölcse (publicus érdem). [...] Mert midőn gondolatainkat anyagi jelek öszvesége által valamelly anyaghoz kötjük s így dologgá teszszük, s e dolgon bármikép - ajándék vagy eladás 
For something to become an intellectual property that justifies legal protection, the need to leave the internal for the external is its condition of possibility (the fact of ownership is internally given). In Toldy's 1838 conception, intellectual property, as it shall be clear, is defined by a bridged inner gap or difference that lies between the idea's immateriality and the now openly public materialization of thought ("binding our thoughts to a material through a set of material signs"). Differentiating between the spiritual and material here is hierarchical by Hegelian logic. And based on the above, distinguishing between internal and external are key for Toldy as it is only possible to talk about the subject of author's rights from the external pole, in relation to the material world - the internal world, which becomes external by means of thought and can be conceptualized as a pre- or postlegal sphere above law and human affairs, providing, at most, a pattern to follow -, however, the embodiment of thought, the transition from internal to external does not necessarily evoke the justification and need for protection by author's rights. According to the quoted part, the "internal estate" may become "external property" in printed form. It is crucial that author's rights, unlike texts published in print, cannot cover the protection of manuscripts, for it implies a notion that makes a connection between the legal scope and a certain interpretation of publicity: joining the publicity of oral presentation and manuscript culture might be significant across Europe - even after printing has gained ground and separated the fields of manuscript and printed publicity (Tóth, 2017, 20-23.) -, Toldy excludes it from the list of acts that could be interpreted as political from the national community's perspective (supposedly because he preferred open accessibility without local and temporal limitations and the option for democratic verifiability, the remnants of the Enlightenment, one may say). It is not by chance, that one of the main arguments in the legal defense of the work is that creating and publishing a text is "public virtue", that is, its creator increases the nation's cultural-scientific capital, which was seen as the "noblest cause" in nineteenth-century Hungary.

For Toldy, publishing an intellectual work - and by its inverse, not doing so - is a political act. The author is responsible for the community, which also must show accountability for the author. The publication of the text and the law of author's rights waiting for its codification can be identified as two distinct forms of national undertaking of responsibility. The chiastic logic of the individual working for the community and the community protecting them (and their work) gets accentuated here. Still, this structure remained asymmetrical in the Hungarian practice until 1884 (for exemple: Hoitsy, 1884, 163.), which was socially detrimental according to István Apáthy, who scrutinized the first act on author's rights, since this asymmetry hinders the desired progress that would ensure the nation's survival (Apáthy, $1885,3 ; 9$.$) . Looking at it from Toldy's paper, the vulnerability of writers and schol-$ ars that lasted for nearly a century longer - which the common law negated to an extent (T. Szabó, 2011a, 573.) - is not simply a rational (legal and economic) problem that emerged in the period, but it is also the inherent lack of national responsibility, a permanent ethical failure eroding and slowly destroying the national

útján - túl adunk, azt, magában értetik, mindig csak föltételesen teszszük: azaz nem a munkát, a szellem mủvét, s vele az azt újra közölhetési jogot, hanem valami egyedi (individualis) dolgot, példányt, példányokat, adunk el." 
community's body from the inside. It is not unlikely that the 1884 law's protectionist features should be interpreted as compensation for partly these failures.

According to Toldy, the published text is inalienable from its author for three main reasons. 1) The text comes to exist as the direct consequence of the author's personal faculty present and functional since birth ("the fruit of our freely grown inborn powers and talents" [my emphasis - G. B.], which also means that those who do not possess such power/talent cannot make any claims for the results - as they can have neither a direct nor an indirect effect on talent's "free" development process. To a degree, becoming the medium of talent, or to be more precise, always already existing as one ensures ownership. 2) The finished work is a kind of investment that includes acquiring the technical knowledge required for writing, as well as the time spent working on the text, the income loss for the period, and all indispensable expenditure. The author's right to see the financial rewards of the investment is warranted by the economic argument for the equation of investment and return. 3) As it has been touched upon already, the services rendered for the country through the work of art have a moral aspect that is inscribed into the relationship between the author and the text, which means that not acknowledging ownership offends a pillar of national identity, the ideal of patriotic attitude manifested by the author's eminent efforts, as opposed to recognizing proprietary rights, which reinforces it. The moral foundation of ownership is secured by the need to maintain the national community's identity.

Toldy's implicit model of the author places the author's most important traits in anthropological, techno-economic and moral dimensions with all the above in mind. Consequently, the author for him is the medium of talent, who, by virtue of having invested time and money in acquiring the technical skills for writing, can form the right to have the community put the written text under legal protection while also keeping an eye on the community's interest -, recognizing in this way the efforts behind it and, in effect, acknowledging him or her as an author. It is worth noting that by this, Toldy puts not only the work of art but the writer's whole being under the protection of author's rights, as the second argument may potentially dedicate the author's entire life to preparing for the text's completion. The product, which means here the linking of the idea to a material vehicle, evokes the author's three qualities and puts all of them in motion. That who violates the author's rights, attacks the author's constitution. That who attacks the author's constitution, attacks the nation.

In connection with one of his examples, Toldy raises the question that determines the whole paper's interpretability. The question concerns the wronged authors and the potential decrease or complete vanishing of their eagerness for action: "will and can that who is stolen from find the notion of continuing their work, if vos non vobis?" (Toldy, 1838, 715; 1840, 163.) As cultural production is not simply the individual's interest, but also that of the nation - moreover, it is primarily that of the nation in the nineteenth century -, Toldy represents stealing from the author, the inheritors and the equitable publisher as robbing the country, when he shows a glimpse of the diminishing creative energies potentially induced by surreptitious editions. He identifies reprints as an antinational act, relying on the ultima 
ratio of the political talk in the reform era, for they ceaselessly threaten to close the most important scenes for the articulation of the national spirit, that is, scientific and literary discussions (works of fine literature [in Toldy: poetry - Vaderna, 2017, 20.] and scholarly papers are equally "the fruit of the noblest talents used for the noblest causes" [my emphasis - G. B.]).

In the light of the above, it is not really surprising that in his imposing essay revising and expanding on the topic of author's rights, published in 1840, Toldy goes beyond writer's property as a strictly legal matter and puts the "sacred right of author's property" (Toldy, 1840, 157.) in the center. This sanctity refers to not just the ultimately divine protection of author's rights made accessible in the nation's medium, but also to the fact that the text's author, whether they like it or not, must take responsibility for their work even "against their will" (Toldy, 1840, 164.), in other words, he must show respect for this sacred phenomenon.

This form of assuming responsibility, however, does not only appear in legal and moral dimensions. Although in Toldy's paper the finished work may seem to belong to its author in a conventional, historically and culturally coded way - after all, the author who voluntarily confers his or her own work's authorship to another person will be bound again to what he or she abandoned by the power of "public opinion" as soon as the real author's identity comes to light -, it is crucial to see that the community's power which appears to create and maintain the convention is sustained from the same causal relationship, or rather: it watches over the causal relationship that can be only covered up but never undone, and which had stood between the "creature and the creator" before the emergence of the communal dimension (lbid.). Conventionality, therefore, cannot be more than an effect for Toldy, an effect which is merely the repetition of a more original and motivated structure. Toldy stabilizes the cause-effect relationship between author and text by interposing the authority of divine sanctity, entrusting the national community as well as God's instances with the legitimization of the much pressed author's rights regulation.

Author's rights are supposed to institutionalize the connection between author and text, which is sacred by default but preserved in that state by the community. The sacred relationship between author and text entails the imperative of inalterability in the case of "philosophical, political, rhetorical, poetic" works (Toldy, $1840,171$.$) - which means that these types of texts, in contrast with the quickly$ outdated informative scholarly papers, cannot be reworked in a future edition, only amended with comments, at most -, as the printed text means "the utterance of the author's spirit" (Ibid.). Toldy argues that the authorial subject can get lost in their work through their "intention", or through its "purely" conveyed form in the text (Ibid.). The author's individuality, however, incorporates the inscription of the national spirit, as the finished work carries the author's intention (this latter is also structurally motivated by the national spirit). The mid-nineteenth-century author is imbued with the national spirit, and the work is imbued with the author's spirit as well as that of the nation. The author always already creates in the state of national precedence, which also has an impact on the work itself. National and nationally preconditioned individual spirit are sounded in unison, inseparably from each 
other. Thought, which is after all the materialization of spirit, is an act of flawless mediation at this moment: the spirit's voice reaches us clearly in the words of the philosophical, political, rhetorical or poetic text. The literary work is an eminent nineteenth-century form of the spirit's presence. This presence connects land and sky, individual and community, citizen and nation, the theological and the political dimension.

As in the literary utopia announced by Toldy in the 1840s, national poetry must be born from the national language, moreover, it must happen - putting one of the period's most basic oppositions in motion (organic/technical) (T. Szabó, 2011b, 252.) - in a deeply organic, technically unaffected way (Margócsy, 2013, 243.); the structural move of the idiomorphic, sacred connection between text and author must be introduced on an institutional level as a natural bond that will be acknowledged in the newly established law and order that is more appropriate than before and stages the inherently coded system of artistic creation in artistic production, thus limiting the further opportunities for the development of natural culture. By this, Toldy represents the relationship between text and author - as a relationship fundamentally connected to and motivated by the internal world, and which precedes and structures law -, as one to be protected by law, but in a consistent fashion, he pulls it out of the legal domain all the same. The sanctity of the author-text relation, which must serve as the fundament for author's rights, is inscribed in the constitution of texts that convey the manifestation of spirit in an exemplary manner. Codification, as the forum where justice and rightfulness are enforced, has no way to sever this bond. In Toldy's papers, the attempt to canonize writing as a profession - though the work of art can never become the medium of pure personality (this is not an option for Toldy) - can be also seen as the attempt to canonize an expressive view of literature. Yet, it is much more than that. The author's new model is built up from theological, anthropological, moral, and what would have been odd earlier, and outright blasphemous in the Christian tradition, technical and economic dimensions. Toldy had a great influence on thinking about authorship in the nineteenth and twentieth century, by having drawn up and announced this remarkably complex and efficient model, the most important elements of which he held on when the Kisfaludy Társaság chaired by himself had its committee develop the proposal of author's rights (Völgyesi, 2007, 28-29.).

Toldy's papers play a crucial role in the history of founding the modern literary consciousness, because they were the first in Hungary to outline and attempt to institutionalize the figure of the writer as the representative of a recognized profession. In his view, writers deserve to be paid for their work, as they occupy themselves in a profession which is on par with any other - or actually superior to them, in Toldy's eyes. For this reason, the announcement of his claims is not to be considered as turning against the common interest. Professional, technical knowledge, techné is required for writing, although it does not play the sole or leading role during the creative process. Already in Toldy's early works, the writer has become an economic agent and the representative of a profession emphatically in the service of the nation. 


\section{References}

Népszámlálás (1871): A magyar Korona országaiban az 1870. év elején végrehajtott népszámlálás eredményei. szerk. Az Országos Magyar Kir. Statistikai Hivatal. Pest: Athenaeum.

Népszámlálás (1893): A Magyar Korona országaiban az 1891. év elején végrehajtott népszámlálás eredményei. I. rész. Általános népleirás. szerk. Az Országos Magyar Kir. Statisztikai Hivatal. Budapest: Pesti Könyvnyomda.

Népszámlálás (1920): A Magyar Szent Korona országainak 1910. évi népszámlálása. Hatodik rész. Végeredmények összefoglalása. szerk. A Magyar Kir. Központi Statisztikai Hivatal. Budapest: Athenaeum.

Népszámlálás (1941): Az 1930. évi népszámlálás: VI. rész: Végeredmények összefoglalása: Továbbá az 1935., 1938. és 1939. évi népösszeírások végeredményei. szerk. A Magyar Kir. Központi Statisztikai Hivatal. Budapest: Stephaneum Nyomda.

Ady Endre (1918): Kaffka Margit versei, Nyugat, 10. évf., 9. sz., 789-790.

Apáthy István (1885): A szerzői jogról szóló törvény (1884. XVI. t. cz.) méltatása jogi és gazdasági szempontból: Székfoglaló értekezés. Budapest: Magyar Tudományos Akadémia.

Balogh Gergő (2017): Gondolkodás és beszéd, írás és olvasás kultúrtechnikái a magyar népiskolai oktatásban, 1869-1925. Irodalomtörténet, 98. évf., 2. sz., 252-276.

Dávidházi Péter (2004): Egy nemzeti tudomány születése: Toldy Ferenc és a magyar irodalomtörténet. Budapest: Akadémiai Kiadó.

Barbier, Frédéric - Lavenir, Catherine Bertho (2000): Histoire des médias. Paris: HER/ Armand Colin.

Betting, Ronald V. (1996): Copyrighting Culture: The Political Economy of Intellectual Property. Boulder - Oxford: Westview Press.

Bodó Balázs (2011), A szerzői jog kalózai: A kalózok szerepe a kulturális termelés és csere folyamataiban a könyvnyomtatástól a fájlcserélő hálózatokig. Budapest: Typotex Kiadó.

Eötvös Károly (1884): Hozzászólása. In Az 1881. évi szeptember hó 24-ére hirdetett országgyülés képviselőházának naplója: XV. szerk. P. Szathmáry Károly. Pest: Pesti Könyvnyomda Részvénytársaság.

Foucault, Michel (1996): What is an Author?. In Michel Foucault, Language, Counter-Memory, Practice: Selected Essays and Interviews, transl. Donald F. Bouchard - Sherry Simon, ITHACA New York: Cornell UP. 113-138.

Hansági Ágnes (2014): Tárca - regény - nyilvánosság: Jókai Mór és a magyar tárcaregény kezdetei. Budapest: Ráció Kiadó.

Hoitsy Pál (1884): Hozzászólása. In Az 1881. évi szeptember hó 24-ére hirdetett országgyülés képviselőházának naplója: XV. szerk. P. Szathmáry Károly. Pest: Pesti Könyvnyomda Részvénytársaság.

Horváth János (2005): Irodalomtörténeti munkái I., Osiris, Budapest, 2005.

Ignotus (1985): Emma asszony levelei: Egy nőimitátor a nőemancipációért. Magvető, Budapest, 1985.

Kittler, Friedrich A. (1995): Aufschreibesysteme 1800-1900. München: Wilhelm Fink.

Kulcsár-Szabó Zoltán (2006): Az „,alapviszony” Horváth Jánosnál és Thienemann Tivadarnál. 
In Szerep és közeg: Medialitás a magyar kultúratudományok 20. századi történetében. szerk. Oláh Szabolcs - Simon Attila - Szirák Péter, Budapest: Ráció Kiadó. 40-56.

Lugosi András (2007): A szerelem bolondja?: Jogi-antropológiai tanulmány az öregségröl és az örökségről. Budapesti Negyed, 15. évf., 4. sz., 360-410.

Margócsy István (1999): Petőfi Sándor, Budapest: Korona Kiadó.

Margócsy István (2013): „...A férfikor nyarában...”: Tanulmányok a XIX. és XX. századi magyar irodalomról. Pozsony: Kalligram Kiadó.

Mezei Péter (2004): A szerzői jog története a törvényi szabályozásig (1884: XVI. tc.). Jogelméleti Szemle, 5. évf., 3. sz. http://jesz.ajk.elte.hu/mezei19.html

Papp Borbála - Sipos Balázs (2017): Modern, diplomás nő a Horthy-korban. Budapest: Napvilág Kiadó.

Szajbély Mihály (2005): A nemzeti narratíva szerepe a magyar irodalmi kánon alakulásában Világos után. Budapest: Universitas Kiadó.

Szajbély Mihály (2010): Jókai Mór. Pozsony: Kalligram Kiadó.

Szegedy-Maszák Mihály (2008): Megértés, fordítás, kánon. Pozsony: Kalligram Kiadó.

[Toldy] D. Schedel Ferenc (1838): Néhány szó az iroi tulajdonról: 's kérelem a' folyóiratok' kiadóihoz. Athenaeum, 2. évf., 1. sz., 705-717.

[Toldy] Schedel Ferencz (1840): Az irói tulajdonról, Budapesti Szemle, [Heckenast Gusztáv, Pest], 1. évf., 1. sz., 157-237.

Török Zsuzsa szerk. (2016): Angyal vagy démon: Tanulmányok Gyulai Pál Írónőink címü írásáról. Budapest: reciti Kiadó.

T. Szabó Levente (2008): A tér képei: tér, irodalom, társadalom. Kolozsvár: Komp-Press Kiadó.

T. Szabó Levente (2011a): A modern magyar szerzőség feltalálása és ideológiái: a szerzői jog első magyar törvényéről. 57. évf., 4. sz., 570-591.

T. Szabó Levente (2011b): Az irodalmi határidő megjelenése és a modern időbeliség új tapasztalata Gyulai Pálnál és kortársainál. In Újrateremtett világok: Írások Cs. Gyimesi Éva emlékére. szerk. Berszán István - Gábor Csilla - Balogh F. András. Budapest - Kolozsvár, Argumentum Kiadó.

Tüskés Gábor (2006): Az irodalomtudomány és -kritika XVIII. századi történetéhez: Koncepciók, módszerek, kutatási lehetőségek. In Historia litteraria a XVIII. században. szerk. Csörsz Rumen István - Hegedüs Béla - Tüskés Gábor. Budapest: Universitas Kiadó, 1542.

Tóth Zsombor (2017): A kora újkori könyv antropológiája: Kéziratos nyilvánosság Cserei Mihály (1667-1756) írás- és szöveghasználatában. Budapest: reciti Kiadó.

Vaderna Gábor (2017): A költészet születése: A magyarországi költészet társadalomtörténete a 19. század első évtizedeiben. Budapest: Universitas Kiadó.

Völgyesi Orsolya (2007): Egy siker kudarca: Kuthy Lajos pályafutása. Budapest: Argumentum Kiadó.

Martha Woodmansee (1994a): On the Author Effect: Recovering Collectivity. In The Construction of Authorship: Textual Appropriation in Law and Literature. ed. Martha Woodmansee - Peter Jaszi. Durham - London: Duke UP. 15-28.

Martha Woodmansee (1994b): The Author, Art, and the Market: Rereading the History of Aesthetics. ITHACA New York: Columbia UP. 